\section{1. 脳動脈瘤の治療：現状と問題点}

$$
\begin{aligned}
& \text { 三重大学大学院医学系研究科脳神経外科学 } \\
& \text { 滝 和郎 }
\end{aligned}
$$

脳動脈瘤の治療は血管内治療と開頭手術の両方が可能に なっており，実際の治療の現場では，その選択に迷うことも 多い，急性期動脈瘤については ISAT の研究成果で，主たる 治療法に血管内治療を採用する施設が増加してきている。 ど のような動脈瘤が血管内治療に向いているのかを施設内で明 らかにしておく必要がある。未破裂動脈溜は初回破裂を予防 する目的での治療が主として行われており, 日常生活を改善 させるという目的の急性期動脈瘤の治療選択とはおのずと異 なっている。また治療選択は大部分が海外の治療報告を基に 論じられており，国内事情と異なることをよく理解しておか ねばならない，また血管内手術は非常な勢いで改良されてい るが, 薬事ならびに保険収載の遅延により, 現実の国内での up-to-date の治療は世界の時流から遅れているものであり， このことも治療の選択に大きく影響するところである，各問 題点について提起する

\section{2. 本邦における末破裂脳動脈瘤の自然歴と治療成 績：UCAS Japan 中間報告}

UCAS Japan 事務局 東京大学医学部脳神経外科内 森田 明夫

【目的】UCAS Japan（日本末破裂脳動脈瘤悉皆調査）は， 未破裂脳動脈瘤の自然歴・治療に関するリスク検証, データ バンクの構築を目的とした前向き研究である. UCAS Japan 登 録例の最新デー夕を報告する。【方法】参加施設において 2001 年 1 月から 2004 年 4 月までの間に発見された治療例・ 経過観察例すべての未破裂脳動脈溜の診断時状況，3力月・ 12 力月・ 36 力月における経過観察を，インフォームド・コ ンセント取得後オンライン登録する。【結果】開始 54 力月 (2005 年 6 月）の段階で参加施設は 404 施設, 登録症例数は 6,632 例, 動脈瘤数は 8,150 個である. 総経過は 10,836 人・ 年である。男女比は $1: 2$, 中間年齢は 63 歳である。瘤のサ イズは 3〜 45 mm（中間 $5 \mathrm{~mm}$ ), 部位は中大脳動脈 $(33 \%)$,

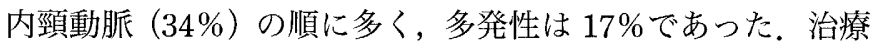
は 2,962 例に適応された.【結論】インターネットを用いた大 規模調查により，未破裂脳動脈瘤に関する重要な情報が収集 されている，今後さらに症例の追跡を徹底し，未破裂脳動脈 瘤の治療方針決定に資するデー夕構築を目指している。

\section{Clip first 施設でのコイル塞栓術の役割}

千葉県救急医療センター脸神経外科

小林 繁樹, 宮田 昭宏, 大石 博通, 石毛 聡, 中村弘

【日的】われわれは, SAH 症例に対しては急性期開頭 clipping 術を基本方針とし，GDC が使用可能となった 1997〜 2003 年までは, 重症度, 年齢, 瘤の部位などより直達手術が 不適と判断された症例には，急性期コイル塞栓術を行ってき た.このような治療方針の下で, 各治療法が選択された症例 の特徵と治療成績について検討した。【対象】対象は, 発症 4 日以内に来院し根治的治療が行われた囊状動脈瘤 212 例で ある.【結果】(1)開頭 clipping 術症例 (DS 群) は 138 例 (65\%), コイル塞栓術症例（GDC 群）は 74 例 (35\%) で, 後者で有 意に高齢であった. (2)H \& K Grade 4-5 の重症例の占める割 合は DS 群 18\%, GDC 群 $42 \%$ であった。(3VA 系動脈瘤の割 合は DS 群で $2 \%$, GDC 群 $38 \%$, 逆に MCA 動脈瘤は DS 群 で 38\%, GDC 群 1\%であった. (4)重症例, 高齢者, VA 系動 脈瘤の治療成績は GDC 導入前に比べて改善した. (5)多発動 脈瘤症例で両治療法の併用が有用と思われた症例があった。

【結論】Clipping first の基本方針においても約 35\%の症例で coil 塞栓術が行われ, 特に高齢者, 重症例, VA 系動脈瘤症例 の治療成績が改善した。

\section{4. コイル塞栓術を第一選択とした急性期破裂脳動 脈瘤の治療成績とその限界}

\author{
立川綜合病院循環器・脳血管センター脳神経外科 \\ 阿部 博史, 本山浩, 土屋 尚人
}

【目的】 2001 年以降，急性期破裂脳動脈瘤に対して可能な 限り coil 塞栓術を第一選択としてきた。 5 年間の治療成績か ら反省も含め限界について検討する。【対象と方法】コイル 塞栓術で治療した急性期破裂囊状動脈瘤 104 例（同期間 clipping 5 例), 動脈瘤部位: IC : $22, \mathrm{MCA}: 25, \mathrm{ACA}+\mathrm{Acom}: 44$, $\mathrm{V}-\mathrm{B}$ 系: 13 . H \& K Grade : I $: 10$, II $: 34$, III $: 31$, IV $: 27$, $\mathrm{V}: 2$. 3DDSA から最適な working angle を選択. 手術は全麻 下.血腫伴うものはコイル塞栓術後に開頭血腫除去術を施行. 術後腰椎ドレナージを留置し UK を骾注.【結果】塞栓率: 7 例に dome filling 残存. 合併症: 症状が残存した術中出血 1 例, 脳梗塞 2 例. 症候性血管攣縮：一過性 10 例, 症状残存 6 例. $\mathrm{NPH} ： 14$ 例. 退院時 $\mathrm{mRS} ： 0-$ II 72 例 $(69 \%)$. 再出 血：急性期 5 例（broad neck 4 例と $2 \mathrm{~mm} の$ small），4 年後 1 例. 追加塞栓：13 例 (14\%).【結論】再出血例を減らすこ とが最大の課題であり, 血腫を伴う bleb を有する broad neck 動脈瘤と $2 \mathrm{~mm}$ 以下の small 動脈瘤には限界がある. Neck 面 が残るコイル塞栓術の限界として再塞栓を常に考慮した follow が必須である。 